\title{
Comparative advantage in Vietnam's agricultural exports to Australia
}

\author{
Mong Long Hoang \\ Ho Chi Minh City University of Foreign Languages and Information \\ Technology (HUFLIT), Vietnam
}

\begin{abstract}
This study determines the comparative advantage of Vietnam's agricultural products based on the index of comparative advantage (RCA - Revealed Comparative Advantage). The research results on the UNComtrade database show that Vietnam maintained 8 commodity groups with revealed comparative advantage in the period 2000 - 2020. Contributing to the increase of Vietnam's exports to Australia one partly due to strong market demand, appropriate industry structure, and a significant part from the factor of competitive advantage, especially in the period $2007-2015$. Vietnam's exports to the Australian market are those with comparative advantages. Therefore, with the trend of trade liberalization increasingly strong in the region, Vietnam has the opportunity to take advantage of market factors and this process will promote the creation of very good trade between Vietnam and some economies in the region.
\end{abstract}

Keywords: comparative advantage, agriculture products, RCA

*Corresponding author: Mong Long Hoang; Email: longhoanghu10@gmail.com DOI: https://doi.org/10.37227/IJEKM-2021-03-134

\section{Introduction}

Australia is considered the most competitive and dynamic import market in the world, with highquality products equivalent to that of the US and EU. Every year, Australia imports about 1.7 to 2 billion USD of vegetables and fruits and 20 million USD from Vietnam. According to statistics of the General Statistics Office of Vietnam, in January 2021, exports from Vietnam to Australia grew by $62.08 \%$ over the same period. Two-way turnover between Vietnam and Australia was estimated at nearly $\$ 873$ million, up $39.92 \%$ over the same period last year, of which Vietnam's export turnover to Australia reached nearly $\$ 392$ million, up $62.08 \%$, despite the impact of the disease Covid 19. However, these numbers do not fully demonstrate Vietnam's comparative advantage in agricultural exports to the Australian market. This research will focus on answering 3 research questions: what are the main agricultural products of Vietnam? What is Vietnam's comparative advantage in exporting agricultural products? And: what policy recommendations are appropriate in the export of agricultural products from Vietnam to Australia? This article is of great importance because it shows the competitive advantage of Vietnamese agricultural products compared to other countries. Since then, boosting exports with key agricultural products as well as expanding the scale of other agricultural products, resulting in higher profit margins in potential markets and high value in the Australian market.

Trade theories from A. Smith's absolute advantage, D. Ricardo's relative advantage, or the Heckscher-Ohlin model explain the benefits of concentrating national resources on the production 
of products with comparative advantage to increase the well-being of the economy. But the limitation of these theories is that they have not shown how to measure a country's comparative advantage in all commodities in the trade relations between economies. Using trade theories in measuring country comparative advantage makes it difficult to analyze inputs due to the dynamic relationship and complexity of factor costs. Derived from Balassa (1965), the Revealed Comparative Advantage (RCA) index is calculated based on comparative advantage theories and historical data of product exchange between the nations. Accordingly, a country reveals its comparative advantage in a particular product if the proportion of that product in the country's export turnover is greater than that of the product in the world's export turnover. The RCA index has been widely used in the study to assess the competitive advantage over the trading system of an economy, such as the studies of Ferto \& Hubbard (2003), Utkulu \& Seymen (2004), Seyoum (2007), Shinyekwa, Isaac \& Othieno (2011), and Esmaeili (2014). However, the RCA index contains some limitations because it only measures the advantage of goods that can only be considered internally in the economy and cannot directly compare the advantages between the goods of countries together, moreover, because based on past export data, so the RCA index only shows the status of comparative advantage revealed within the economy rather than a predictor policy orientation. Overcoming a few minor weaknesses, the RCA remains a reliable method of assessing the comparative advantage in the export of goods of an economy. In this article, the author uses the RCA model to answer three research questions.

\section{Literature Review}

Vietnam and Australia have now become each other's important economic and trade partners. Currently, Vietnam is one of the 15 countries with the largest import-export turnover in Australia. Vietnam and Australia are trading partners through the Free Trade Agreement (FTA), ASEAN Australia - New Zealand (AANZFTA) entered into force in 2010, and the Comprehensive and Progressive Agreement for Trans-Pacific Partnership (CPTPP) entered into force at the end of 2018 (ASEAN Economic Community Department, 2018). Based on these agreements, most of Vietnam's goods exported to Australia will enjoy a preferential tax rate of $0 \%$ and many other favourable conditions (Australian Embassy in Vietnam, 2018). However, the capacity and value of Vietnam's exports and investments to Australia are still very modest, and Vietnam's fresh agricultural products exported to Australia only occupy a small position in the total size of the Australian market. According to the General Statistics Office of Vietnam, in 2020, two-way trade turnover between Vietnam and Australia increased by 3.94\% to nearly $\$ 8.3$ billion (GSO of Vietnam, 2020). Particularly in the first four months of 2021, the total import-export turnover between the two countries reached 3.63 billion USD, up $33.85 \%$ over the same period last year. Exports of Vietnam and Australia to each other's markets increased (GSO of Vietnam, 2021). This is a very important result as the COVID-19 pandemic has caused unprecedented disruption to global trade and several countries, including those in Southeast Asia, are restructuring supply chains and bring them home.

As an island nation with an important agricultural industry, Australia's quarantine regulations are very strict. All imported plants, whether fresh or not or plant parts such as fruits, seeds, twigs, tubers, etc., as well as wood and all products made from wood, bamboo, etc are all subject to quarantine and must be transferred to the phytosanitary agency. Imported products found to be contaminated will have to be disposed of, destroyed, or returned at the owner's expense. Some ornamental plants, seeds, and clean vegetables must be licensed before being imported (Australian Academy of Science, 2017). Currently, Australia has only opened the market to four types of fresh Vietnamese fruits: longan, lychee, mango, and dragon fruit (MPI 2018). Therefore, diversifying export products and finding new opportunities through trade in processed agricultural products is one of the most favourable directions for Vietnamese businesses and farmers. The proof is that in two years 2019 and 2020, Vietnam's frozen durian exports to the Australian market are well received and consumed quickly (GSO of Vietnam, 2021). Most recently, RI6 durian has also been promoted by the Trade Office, successfully building a typical Vietnamese durian image, creating a

International Journal of Education and Knowledge Management (IJEKM) 
competitive effect with other countries' products. In addition, Vietnam's cashew nut is a commodity that accounts for a large proportion of Australia's total cashew imports, accounting for $2 / 3$ of the total import market share (GSO of Vietnam, 2021). However, the type of cashew nut exported from Vietnam to Australia is still mainly cashew nut. Meanwhile, in the market, imported cashew kernels, processed, packaged individually, or in combination with other nuts, are abundant in supermarkets, retail stores, and convenience stores at cheap prices. sell much higher. Therefore, to increase the turnover of this item, it is necessary to encourage businesses to research processed products that are suitable for consumers' tastes, thereby bringing high added value to imported cashews. Vietnam, from which the export turnover of this item will also increase.

Although there have been many efforts and successes to develop and expand the export market of agricultural products the export of key agricultural products of Vietnam still faces many difficulties such as large-scale processing facilities small, scattered; outdated production technology, mainly simple preliminary processing, only a few uses modern processing lines, reaching 25\%-30\%, while the average ASEAN countries reach 50\%; management and business capacity are still limited ((MPI 2018). Key agricultural products have low competitiveness; no brand in the international market; mainly exported in raw form, so the added value is not much. Along with that, technical barriers are a big difficulty for Vietnamese enterprises when Vietnamese agricultural products exported only reach international standards about $5 \%$; the export market of agricultural products mainly focuses on countries in the region and is always subject to competition from Thailand, India, Indonesia, etc. also have similar products (Dang et al., 2014; Le, 2016). Therefore, this article has an important role in pointing out the competitive advantages for agricultural products exported to the Australian market and make recommendations to improve competitive advantages for agricultural products in the coming time.

\section{Methodology}

The concept of comparative advantage was introduced in 1817 by David Ricardo. Comparative advantage is determined by comparing the production costs of different goods within a country. A country is said to have a comparative advantage in the production of a good if the cost of producing that good is lower than the cost of producing another good. Liesner (1958) based on the theory of comparative advantage and put forward the idea of evaluating a country's comparative advantage product through the analysis of that country's exports. A country's main exports are usually those in which the country has a comparative advantage. By 1965, Bela Balassa had developed a comparative advantage based on a calculation by dividing the share of exports of a good (or group of goods) of a country by the share of exports of that good worldwide. world. claim and call it Revealed Comparative Advantage. Balassa RCA or BI (Balassa Index), is one of the popular and widely applied methods to calculate comparative advantage between commodities and is used in many research papers. Therefore, this paper is based on the RCA method to estimate the comparative advantage of Vietnam's agricultural products when exporting to Australia to accurately assess and make suggestions to improve the advantage. competition for the item

Many studies using RCA to determine comparative advantage for countries, typically in Southeast Asian countries: China, Japan, South Korea have studies by Elias \& Yousun (2010) and many countries. In the world such as the US, the Netherlands ... and Vietnam uses DRC to measure comparative advantage in international trade. Case studies in agriculture (Bojnec, 2001), industry, tourism (Peterson, 1988), services (Hisanaga, 2008; Seyoum, 2007), ...

In Vietnam, using RCA to determine comparative advantage also has many studies in agriculture, typically Nguyen Thien (2011), Institute of Policy and Strategy for Agriculture and Rural Development (2008), Trinh \& Nghi (2011), Le Xuan Tao (2015), Vo Khac Huy (2014), Le Tuan Loc (2015) and research on national comparative advantage (Vietnam) compared with partner country by the index of Partnership Commercial Advantage (PCA or LangIndex). The goodwill of a country for each partner is determined based on the correlation of the ratio between the country's export turnover and import turnover with the partner in a certain period. the ratio between the 
country's total exports and total imports in the same category (Nguyen Thuong Lang, 2011). The index of comparative advantage displayed is the ratio of a country's share of this agricultural product to the world's exports of that commodity to its share of total world exports. This study uses quantitative methods to determine the value of RCA in the trade relationship between Vietnam Australia. In which, the calculation of the RCA value - revealed comparative advantage of country $j$ in the product $\mathrm{I}$ in year $\mathrm{t}$ follow the following formula:

$R C A=(X i j / X i) /(W j / W)$

With

RCA: comparative advantage in the expression of country j's export product $i$

Xij: export value of product $\mathrm{j}$ of country $\mathrm{i}$

$\mathrm{Xi}$ : total export value of country $\mathrm{i}$

$\mathrm{Wj}$ : the world's export turnover of product $\mathrm{j}$

W: total world export turnover

Table 1. Revealed Comparative Advantage Level

\begin{tabular}{|l|l|l|}
\hline No. & Group & Revealed Comparative Advantage Level \\
\hline 1 & $0<\mathrm{RCA} \leq 1$ & No Comparative Advantage \\
\hline 2 & $1<\mathrm{RCA} \leq 2$ & Low comparative advantage \\
\hline 3 & $2<\mathrm{RCA} \leq 4$ & Average comparative advantage \\
\hline 4 & RCA $\geq 4$ & High comparative advantage \\
\hline
\end{tabular}

Source: Hinloopen, 2001

When comparing the RCA coefficients of the same item of the two countries, the country with the larger RCA coefficient will have a higher export advantage.

Summing up the above RCA studies, the authors synthesized RCA from 3 points of view: (1) Comparative advantages based on both commercial and production factors, typically in this group there is Lafay index-LI (Lafay, 1992); (2) The only base comparison advantage on the export factor, typically there are measurement indicators such as SI (Dalum et al., 1998), WI (Proudman \& Redding, 2000), and AI (Hoen \& Oosterhaven, 2006); and (3) Advantages based on advantages or neutrality, having a NI index. Summary of comparative advantage indicators in Table 2.

Table 2. Synthesis of Existing Comparative Indicators

\begin{tabular}{|c|c|c|}
\hline Index & $\begin{array}{l}\text { Calculation formula } \\
\end{array}$ & Note \\
\hline BI & $B I_{i j}=\frac{X_{i j} / X_{i}}{X_{w i} / X_{w}}=\frac{X_{i j} / X_{w j}}{X_{i} / X_{w}}$ & \multirow{6}{*}{$\begin{array}{l}\text { RCAij also known as } B L_{i j} ; \\
X_{i j:} \text { Export turnover of product } j \text { of } \\
\text { country } i \text {; } \\
X_{i}=\sum X_{i j}: \text { Total export turnover of } \\
\text { country } \mathrm{i} ; \\
X_{w j}=\sum X_{i j} \text { Total exports of } \\
\text { productsj globally; } \\
X_{w}=\sum i \sum j X_{i j}: \text { Total global exports; } \\
Y_{i}: \text { GDP of country } i ; \\
M: \text { Imports; } \\
M i=\sum j M_{i j}: \\
N \text { : Sectors. }\end{array}$} \\
\hline LI & $L I=\left(1000 \times \frac{X_{i j}-M_{i j}}{Y_{i}}\right)-\left(\frac{X_{i j}+M_{i j}}{\sum_{i}\left(X_{i j}+M_{i j}\right)} \times \frac{1000 \sum_{j}\left(X_{i j}-M_{i j}\right)}{Y_{i}}\right)$ & \\
\hline SI & $S I_{i j}=\frac{B I_{i j}-1}{B I_{i i}+1}$ & \\
\hline WI & $W I_{i j}=\frac{B I_{i j}}{\frac{1}{N} \sum_{j=1}^{N} B I_{i j}}$ & \\
\hline AI & $A I_{i j}=\frac{X_{i j}}{X_{i}}-\frac{X_{w j}}{X_{w}}$ & \\
\hline NI & $N I_{i j}=\frac{\Delta X_{i j}}{X_{w}}=\frac{X_{i j}}{X_{w}}-\frac{X_{w j} X_{i}}{X_{w} X_{w}}$ & \\
\hline
\end{tabular}

Source: Elias Sanidas \& Yousun Shin, (2010)

International Journal of Education and Knowledge Management (IJEKM) 
The Existing Comparative Advantage Index (RCA) is used to measure comparative advantage in 3 common ways: (1) Measure comparative advantages in a given field by comparing calculated values with 1; (2) Determine the advantages between industries within a country or between countries by using a ranking in the order of comparative advantage index value and (3) Determine the comparative (or disadvantage) advantage of a certain country over periods to assess a change in the structure of the comparable industry (Elias Sanidas \& Yousun) Shin, 2010).

Comparative advantages according to the RCA index are measured on the results of consumption (competitiveness) in the international market of a country (export turnover, export market share) compared to the world or compared to the Existing Comparative Advantage Index (RCA) used to measure comparative advantages in 3 popular ways: (1) Measure comparative advantages in a given field by comparing calculated values with 1; (2) Determine the advantages between industries within a country or between countries by using the ranking in the order of comparative advantage index value and (3) Determine the comparative (or disadvantage) advantage of a certain country over periods to assess changes in the structure of the comparable industry (Elias Sanidas \& Yousun Shin, 2010). Comparative advantages according to the RCA index are measured on the consumption results (competitiveness) in the international market of a country (export turnover, export market share) compared to the world or compared to international trade books, bilateral negotiations, negotiations to join international trade organizations, and especially in this topic, the author has used RCA to assess the competitive advantage of the country /product in international trade.

\section{Research Data}

This study uses the World Bank (UNComtrade) SITC commodity code detailed classification of trade data for the period $2000-2020$. This data source is used by the authors to calculate the RCA indices, growth analysis - components to analyze trade flows between Vietnam and Australia.

\section{Comparative Advantages Revealed}

\section{Results}

According to statistics of the Ministry of Agriculture and Rural Development of Vietnam, the total export turnover of agricultural products increased from USD 16.5 billion in 2008 to USD 32.1 billion in 2016 (an increase of $8.7 \%$ per year). In particular, some items with a strong and even increase in export turnover over the years such as cashew nuts (growth of $15.3 \%$ / year), group of fruits and vegetables (growth of $25.2 \%$ ), pepper (growth of $21 \%$ / year), rice products alone have negative growth $(-3.5 \%$ / year). With a high-end market like Australia, it will be one of Vietnam's key markets in the process of market diversification, promoting sustainable exports, and gaining high added value.

The achievements over the years have affirmed Vietnam's position in the field of agricultural products in the world market and showed that agricultural products are an industry with Vietnam's advantages in the international market. This is confirmed by the results of calculating the comparative advantage index of Vietnamese agricultural products in the international arena in recent years. RCA of Vietnam's agricultural products industry continuously increased from 2.3 from 2001 to 4.3 in 2010, and then tended to decrease and the lowest point was in 2019. According to Hinloopen (2001), with RCA $>2$ has shown that Vietnam began to have advantages in this field of agricultural exports. The peak of 2009-2011 Vietnam has RCA $>4$ proves that Vietnam has a great advantage. From 2017-2019 RCA reached above 3 shows that Vietnam has an average comparative advantage (Figure 1). 
Figure 1. RCA of Vietnam's Agriculture sector, 2001-2019

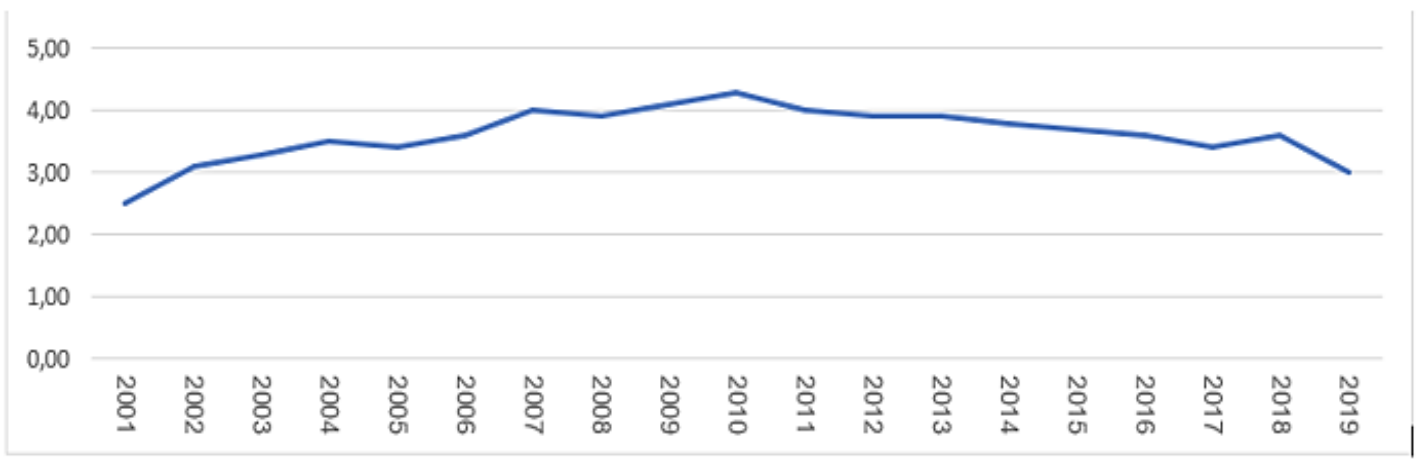

Source: author's synthesis

Figure 2 compares the RCA of Vietnam's agriculture with some major agricultural exporters in the world. China, despite being the country with the largest export turnover of agricultural products, has only the advantage of comparatively average. The RCA of Chinese agricultural products tends to gradually decrease from 3.18 in 2001 to 2.35 in 2019. Like China and Vietnam, the RCA of India and Indonesia's agricultural exports also decreased during the research period and reached 2.52 and 1.67 respectively in 2019 .

\section{Figure 2. Agricultural RCA of some countries}

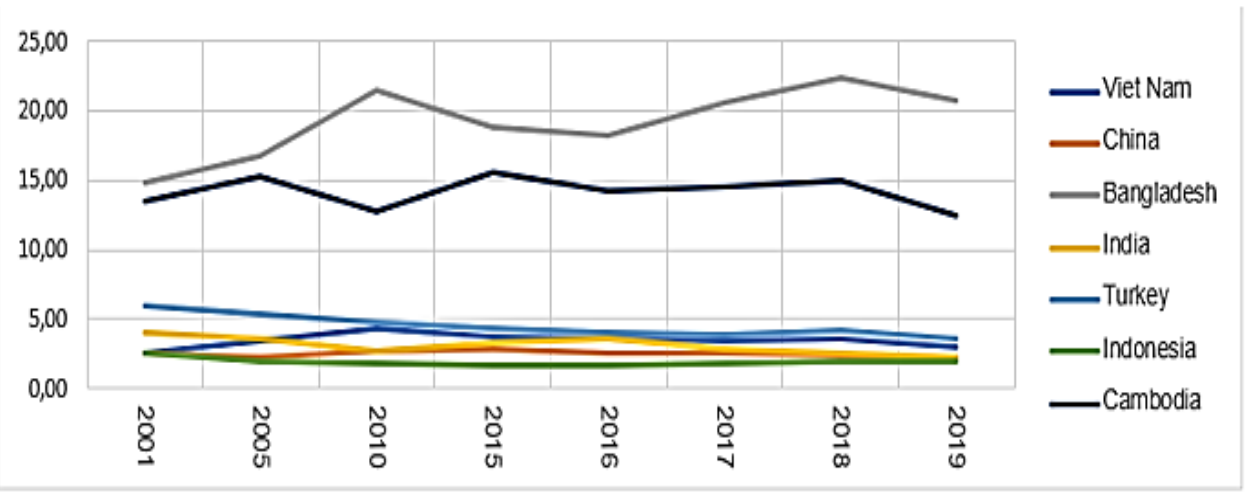

Source: author's synthesis

Meanwhile, Cambodia and Bangladesh have a very high comparative advantage in this field, with RCA ratios of 11.79 and 20.5 respectively in 2019, although the proportion of agricultural export turnover of these two countries is only $1.58 \%$ and $5 \%$ of the total agricultural turnover of the world. Turkey has an average comparative advantage in the agricultural sector with an RCA that remains relatively stable at 3.36. The results of the analysis showed that Vietnam's comparative advantages of agricultural products are higher than those of China, India, and Indonesia but lower than those of Turkey and especially much lower than Bangladesh. 
Table 3. Export Value of Vietnam's Key Goods to Australia

\begin{tabular}{|l|l|l|l|}
\hline \multicolumn{1}{|c|}{ Items } & \multicolumn{1}{|c|}{$\mathbf{2 0 1 7}$} & \multicolumn{1}{|c|}{$\mathbf{2 0 1 8}$} & \multicolumn{1}{|c|}{$\begin{array}{c}\text { Increase/decrease } \\
\mathbf{( \% )}\end{array}$} \\
\hline Export turnover & 3.298 .399 .052 & 3.965 .089 .653 & $20 \%$ \\
\hline Cashew & 133.239 .121 & 110.846 .205 & $-17 \%$ \\
\hline Fruits and vegetables & 28.910 .128 & 42.079 .480 & $46 \%$ \\
\hline Coffee & 28.530 .391 & 39.469 .787 & $38 \%$ \\
\hline $\begin{array}{l}\text { Rattan, bamboo, sed } \\
\text { with sed to rug } \\
\text { products }\end{array}$ & 10.640 .332 & 15.740 .892 & $48 \%$ \\
\hline Products from rubber & 12.138 .803 & & $4 \%$ \\
\hline Peppercorn & 14.246 .727 & 9.642 .284 & $-32 \%$ \\
\hline Rice & 6.188 .840 & 7.208 .092 & $16 \%$ \\
\hline
\end{tabular}

Source: author's synthesis

We can see that the number of exports of Vietnam is quite diverse, focusing on items such as cashew nuts, products from rubber, rice, pepper. The structure of agricultural products shows that there is no big difference between the key items in Vietnam's agricultural exports to Australia. Which, fruits and vegetables and rattan, bamboo, and side products are on the rise in 2017-2018. Especially for fruits and vegetables, according to the Ministry of Industry and Trade, although the negotiation process for each item exported to Australia is difficult and time-consuming (usually 510 years, the fabric takes 12 years, mango takes 7 years), but up to now Vietnam has completed the penetration into this market for lychee (in 2015) and mango (in 2016), creating an additional "playground" for fresh fruits in the country. Dragon fruit is Vietnam's main export fruit with export turnover in 2016 reached 895.7 million USD, accounting for $50.3 \%$ of fresh fruit exports and $36.1 \%$ of Vietnam's total fruit and vegetable exports.

\section{Vietnam's Export Trends to Australia}

Statistics of the General Department of Customs show that in January 2021, the export turnover of two-way goods in Vietnam and Australia increased by $39.92 \%$ compared to the same period last year, estimated at nearly 873 million USD. Exports from Vietnam to Australia increased by $62.08 \%$, much higher than in previous months, reaching nearly 391 million USD.

In 2020, although the epidemic situation seriously affects world trade in general and Australia in particular, the number of consumer goods originating from Vietnam is present in the largest market in Asia-Pacific, increasingly diverse in designs and types. Consumers of "Kangaroo Country" have gradually become more aware of Vietnamese agricultural brands, such as frozen durian, fresh coconut, dragon fruit, labels, and green mangoes. In particular, during the Lunar New Year 2021, Vietnam's goods were not only sold and consumed in Asian supermarkets for the first time but also appeared richly in the distribution system of Australia's two largest supermarket chains, Woolworths and Coles. In addition, based on the situation of domestic crops, the Deal will also plan to support the consumption of Vietnamese agricultural products in Australia through organizing promotion associated with branding. According to statistics of the General Department of Customs of Vietnam, in the first three months of 2021, exports of agricultural and fruit products from Vietnam to Australia had a growth rate of $39.97 \%$ compared to the same period last year, reaching a turnover of more than 19 million USD. 


\section{Discussion}

The number of Vietnamese exports to Australia is quite diverse, but the most valuable exports do not change much. The common point of research articles on Vietnamese agricultural products in recent times and for this study all show that one of the factors that reduce competitiveness is our country's main export agricultural products to Vietnam. mainly goods without technology content, added value in agricultural exports of Vietnam is still low. Most of our country's main export agricultural products are in raw or semi-processed form, so the value obtained is not high. The quality of Vietnamese agricultural products is low, processing technology is outdated. But besides that, in this article, we have pointed out the main export products of Vietnam to the Australian market and pointed out some products that are likely to be exported soon, including cereals, fresh vegetables, and fruits.

Vietnam's agricultural exports to Australia are focused on seven key groups and exports are small compared to the needs of the Australian market. Therefore, Vietnam's agricultural exports to Australia are not commensurate with the potential of the Australian market and Vietnam's export capacity. In the coming time, the opportunity to boost Vietnam's agricultural exports to the Australian market is huge. From an Australian market perspective: Australia is a market with a high purer per person income and growth rate, strong imports of agricultural products compared to the overall level of imports of the world, including many Vietnamese goods with comparative advantages. Australia has a well-ventilated import policy for agricultural products and creates many favorable conditions for enterprises to export agricultural products in this market. From a Vietnamese market perspective: In the coming period, Australia will be a market with great potential for Vietnam in all six key groups. In addition, Vietnamese exporters also left the market gap of three groups of goods: cereals, vegetables, and fruits while these are three Vietnamese groups with quite highly competitive advantages. This is a huge opportunity for exporters of these three groups of goods to study the market for export to Australia. Statistics of Vietnam Trade Deal in Australia, in 2017 and 2018, the import turnover of unprocessed fruits and vegetables from Vietnam is 10-12 times less from China; processed vegetables 19-20 times less. Compared to China because the structure of fruits and vegetables is similar, but the distance is very far, showing the potential of our country is great.

According to the Ministry of Industry and Trade, Vietnam's export of agricultural products to the Australian market is favorable. The reason, according to the roadmap of the ASEAN Australia - New Zealand Free Trade Agreement (AANZFTA), in 2018, Australia will cut the flow of goods import tax from ASEAN, New Zealand to $0 \%$ and in $2020,100 \%$ of the tax line will be cut to $0 \%$. In addition, Australia and Vietnam and several other countries have signed the Comprehensive and Progressive Agreement for Trans-Pacific Partnership (CPTPP). This also opens great opportunities for Vietnam to boost exports to the Australian market shortly. Australia is one of the potential agricultural export markets of Vietnam when in the last 3 years, Vietnamese fabrics, mangoes, and dragon fruit have been officially opened for import into Australia.

In the context of Vietnam's exports being affected by the impact of the world crisis, one issue is that there should be accurate evaluations of the trend of export markets in the following years, the right orientation of the central export market, and the right choices about the potential market. The Australian market is a potential export market for Vietnam's agricultural products that the Government and businesses need to make appropriate efforts to boost exports to this market, contributing to the implementation of the country's export targets.

As we can see, Vietnam's exports to the Australian market are those with comparative advantages. Therefore, with the trend of trade liberalization increasingly strong in the region, Vietnam could take advantage of market factors and this process will promote the creation of very good trade between Vietnam and some economies in the region. On the other side, due to the comparative structure and advantages of Vietnam and some similar countries, there will be strong competition with each other, especially with Indonesia and Cambodia, Bangladesh...

International Journal of Education and Knowledge Management (IJEKM) 
All in all, considered a potential market for Vietnamese enterprises, but in fact, Vietnamese enterprises have many difficulties when entering this market. Therefore, to penetrate this market well, the Ministry of Industry and Trade recommends that businesses pay special attention to further improve the quality of exported goods products, ensuring that technical standards following the requirements of the new market can take advantage of sustainable export opportunities to Australia. When exporting agricultural products to Australia, businesses should pay attention to comply with Australian quarantine regulations on planting areas, packaging facilities, irradiation, packaging, labels, an inspection of pesticide residues right from Vietnam.

\section{Policy Suggestions}

In Australia - a difficult market, to make the most of this opportunity, Vietnamese enterprises need to focus on four points:

Firstly, Vietnamese enterprises need to be more active and proactive in learning about the Australian market and the incentives that Vietnamese exports are entitled to in the AANZFTA Agreement.

Secondly, Vietnamese enterprises also need to diversify and improve the quality of exports to increase the competitiveness of Vietnamese goods in the Australian market.

Thirdly, develop a long-term business strategy. Enterprises need to choose product strategies and strategies to penetrate the Australian market following the needs, the actual situation of the market, and the ability of businesses.

Fourth, focus on branding for goods. The most superior solution is to provide high-valueadded innovation products, better origin than simply providing raw materials and inexpensive goods. This will help elevate the Vietnamese brand, build trust with consumers and change the perception that Vietnam only provides inexpensive products that Australians often think of as inexpensive goods as bad quality goods.

\section{References}

American Psychological Association. (1972). Ethical standards of psychologists. Washington, D. C: American Psychological Association.

Balassa, B. (1965). Trade Liberalisation and "Revealed" Comparative Advantage. The Manchester School, 33(2), 99-123.

Belay Seyoum (2007). Export performance of developing countries under the Africa Growth and Opportunity. Journal of Economic Studies. 34, pp. 515-533

Berzeg, K. (1984). A Note on Statistical Approaches to Shift-Share Analysis. Journal of Regional Science, 24(2), 277- 285.

Dalum, B., K. Laursen and G. Villumsen, 1998. 'Structural Change in OECD Export Specialization Patterns: De-Specialization and 'Stickiness', International Review of Applied Economics, $12,447-467$.

England, T. T., \& Thang, D. N. (2008). Factors affecting Vietnam's trade concentration with Asean+3 (No. NC-05/2008).

Esmaeili, A. (2014). Revealed Comparative Advantage and Measurement of International Competitiveness for Dates. Journal of International Food \& Agribusiness Marketing, 26(3), 209-217.

Elias, S. \& Yousun, S. 2010. Comparison of Revealed Comparative Advantage Indices with Application to Trade Tendencies of East Asian Countries. Department of Economics, Seoul National University.

Ferto, I., \& Hubbard, L. J. (2003). Revealed Comparative Advantage and Competitiveness in Hungarian Agri-food Sectors. World Economy, 26(2), 247-259.

He, D. T., \& Son, N. Van. (2013). Vietnam Agricultural Value Chain in the FTA of Asian Region. FFTC. NACF International Seminar, 1-22 (10-2013). 
Hoen, A. \& Oosterhaven, J., (2006). On the measurement of comparative advantage. Annals of Regional Science, 40, 677-691.

Herschede, F. (1991). Competition among ASEAN, China, and the East Asian NICs: A Shift-Share Analysis. ASEAN Economic Bulletin, 3(March 1991), 290-306.

Hinloopen, J. (2001). On the empirical distribution of Balassa index. Reviewed of World Economics, 137(1), 1-49.

Lang (2011), Proposing the formula for measuring the partner's goodwill (PCA) of a country. Development and Integration Journal, 17(27): 73-77.

Lall, S. (2000). The Technological Structure and Performance of Developing Country Manufactured Exports, 1985-98. Oxford Development Studies, 28(3), 337- 369.

Lafay, G., 1992. The measurement of revealed comparative advantages in M.G. Dagenais and P.A. Muet eds. International Trade Modeling. London: Chapman \& Hill.

Makoto Hisanaga (2008). "Revealed Specialization: Evidence on U.S. International Services," KIER Working Papers 645, Kyoto University, Institute of Economic Research.

Ricardo, D. (1817). Principles of political economy and taxation. London, UK: John Murray.

Peter B. Smith and Mark F. Peterson (1998): Leadership, Organizations and Culture: London: Sage. 195 pages.

Proudman, J. \& Redding, S. (1998). Openness and growth. The Bank of England.

Seyoum, B. (2007). Comparative advantage and competitiveness in services. Journal of Economic Studies, 34(5), 376-388.

Stenfan Bojnec (2001). Patterns of Intra-Industry Trade in Agricultural and Food Products During Transition. Eastern European Economics, 39(1):61-89.

Shinyekwa, Isaac, Othieno, L. (2011). Uganda's revealed comparative advantage: the evidence with the EAC and China. Economic Policy Research Centre (EPRC), 38.http://purl.umn.edu/150474

Thu, N., Van Trung, V., \& Thanh Xuan, L. T. (2015). Assessing the Impact of ASEAN+3 Free Trade Agreements on ASEAN's Trade Flows: A Gravity Model I don't want to be. Mediterranean Journal of Social Sciences, 6(6), 394-401.

Trịnh \& Nguyễn (2011), Determining comparative advantage in black tiger shrimp farming in the Mekong Delta. Scientific Journal of Can Tho University, 3(21).

Trịnh, B. V., \& Nghi, N. Q. (2011). Xác định lợi thế so sánh ngành hàng tôm sú nuôi thâm canh ở Đồng bằng Sông Cửu Long. KINH TÉ VÀ QUẢN TRI KINH DOANH, 6(2), 65-73.

Tao (2015), Exports in the Mekong Delta under the context of Vietnam being a WTO member. Doctoral thesis. Ho Chi Minh City National Academy of Politics.

Thien (2011), Comparative advantage theory and suggestions for Vietnam in the current development context, National Workshop of economic theories in the context of global economic crisis and practice in Vietnam Male.

Utkulu, U., \& Seymen, D. (2004). Revealed Comparative Advantage and Competitiveness: Evidence for Turkey vis-à-vis the EU/15. In European Trade Study Group $6^{\text {th }}$ Annual Conference, ETSG 2004, Nottingham, September 2004 (pp. 1-26).

Utkulu, U., \& Seymen, D. (2004). Revealed Comparative Advantage and Competitiveness: Evidence for Turkey vis-à-vis the EU/15. In European Trade Study Group 6th Annual Conference, ETSG 2004, Nottingham, September 2004 (pp. 1-26). 